\title{
Flavor Profiles of Full-Fat and Reduced-Fat Cheese and Cheese Fat Made from Aged Cheddar with the Fat Removed Using a Novel Process ${ }^{1}$
}

\author{
M. E. Carunchia Whetstine,${ }^{\star}$ M. A. Drake, ${ }^{\star 2}$ B. K. Nelson,, and D. M. Barbano† \\ *Department of Food Science, Southeast Dairy Foods Research Center, North Carolina State University, Raleigh 27695 \\ †Northeast Dairy Foods Research Center, Department of Food Science, Cornell University, Ithaca, NY14853
}

\begin{abstract}
Many consumers are concerned with fat intake. However, many reduced-fat foods, including reduced-fat cheese, lack robust flavors. The objectives of this study were to characterize the flavors found in full-fat cheese, cheese fat, and reduced-fat cheese made from aged Cheddar using a novel process to remove the fat (Nelson and Barbano, 2004). Two full-fat, aged cheeses (9 and $39 \mathrm{mo}$ ) were selected, and the fat was removed using the novel fat removal process. Full-fat cheeses, shredded and reformed full-fat cheeses, corresponding reduced-fat cheeses, and cheese fats were then analyzed using descriptive sensory and instrumental analysis followed by consumer acceptance testing. Cheeses were extracted with diethyl ether followed by isolation of volatile material by high vacuum distillation. Volatile extracts were analyzed using gas chromatography/ olfactometry with aroma extract dilution analysis. Selected compounds were quantified. The 39 -mo cheese was characterized by fruity and sulfur notes, and the 9-mo-old cheese was characterized by a spicy/brothy flavor. Reduced-fat cheeses had similar flavor profiles with no difference in most sensory attributes to corresponding full-fat cheeses. Sensory profiles of the cheese fats were characterized by low intensities of the prominent flavors found in the full-fat cheeses. Instrumental analysis revealed similar trends. Consistent with sensory analysis, there were lower concentrations and $\log _{3}$ flavor dilution factors for most compounds in the cheese fats compared with both the reduced- and full-fat cheeses, regardless of compound polarity. Consumers found the intensity of flavor in the reduced-fat cheese to be equal to the full-fat cheeses. This study demonstrated that when fat was removed from aged full-fat Cheddar cheese, most of the flavor and flavor com-
\end{abstract}

\footnotetext{
Received July 10, 2005.

Accepted September 7, 2005.

${ }^{1}$ Use of names, names of ingredients, and identification of specific models of equipment is for scientific clarity and does not constitute any endorsement of product by authors, Cornell University, North Carolina State University, the Southeast or the Northeast Dairy Foods Research Centers.

${ }^{2}$ Corresponding author: mdrake@unity.ncsu.edu
}

pounds remained in the cheese and were not removed with the fat.

Key words: reduced-fat cheese, sensory analysis, gas chromatography/olfactometry

\section{INTRODUCTION}

Fat reduction in the American diet is a main focus for both consumer and food manufacturers. There is overwhelming scientific evidence that a diet high in saturated fat contributes to increased rates of both cancer and coronary heart disease (Woteki and Thomas, 1993). A 2000 study shows that $41 \%$ of all shoppers are controlling their fat intake (National Marketing Institute, 2000; Sloan, 2001). Reduced-fat cheese is becoming more popular, but it is difficult to produce a high-quality, reduced-fat cheese with comparable flavor and texture properties to full-fat cheese (Bryant et al., 1995; Drake and Swanson, 1995). Reduced-fat cheese generally has a higher moisture content to better mimic the texture of full-fat Cheddar (Drake and Swanson, 1995). The increased moisture content, as well as the reduction in fat, modifies the microenvironment of the cheese, and this changes both bacterial growth patterns and modifies enzymatic activity (Mistry, 1995; Nauth and Ruffie, 1995), which may affect flavor and texture development during aging.

Reduced-fat cheese is usually made from low- or reduced-fat milk. However, Nelson and Barbano (2004) developed a novel way to physically remove the fat from a full-fat aged Cheddar cheese. In aged cheeses, flavor has already developed, and by removing the fat after the aging process has occurred, they theorized that the nonfat portion of the cheese would retain the characteristic flavors associated with aged Cheddar cheese, resulting in a flavorful reduced-fat cheese. Most flavor compounds are nonpolar, and fat is a flavor carrier of these hydrophobic compounds (Relkin et al., 2004). Therefore, one might assume that when the fat is removed, the flavor will be lost as well. However, McGugan et al. (1979) fractionated aged Cheddar cheese into water and fat fractions and evaluated them using sensory analysis. That study concluded that the watersoluble extract contributed to the intense aged Cheddar 
flavor and that the fat-and-water-insoluble protein matrix contributed little to this flavor.

Consumers indicated in a 1997 market study that they would increase their consumption of reduced-fat cheese if great-tasting, reduced-fat products were available (Gorski, 1998). Therefore, improved flavor is a main goal for the manufacturers of reduced-fat cheese. Preliminary sensory work with aged Cheddar cheese made with the novel fat removal process (Nelson and Barbano, 2004) indicated no loss of desirable flavor intensity, but a more systematic study on the flavor of these reduced-fat cheeses is needed. The objectives of this study were to apply sensory and instrumental analyses to characterize the flavors found in full-fat cheese, cheese fat, and reduced-fat cheese made from aged Cheddar using a novel process to remove the fat (Nelson and Barbano, 2004).

\section{MATERIALS AND METHODS}

\section{Reduced-fat Cheddar Cheese Manufacture}

Two 18-kg blocks of full-fat Cheddar cheese were obtained from a commercial manufacturer of aged Cheddar cheese. The cheeses were 9 and 39 mo old when they were used to produce reduced-fat cheese. These cheeses were selected by an experienced grader to display characteristic, distinct, and intense aged Cheddar cheese flavors. Three highly experienced descriptive panelists at North Carolina State University, each with $>500 \mathrm{~h}$ experience with sensory analysis of Cheddar cheese, also screened these 2 cheeses for distinct and intense aged Cheddar cheese flavors prior to initiation of the experiment. Each 18-kg block arrived at Cornell University vacuum-packaged and was held at $6^{\circ} \mathrm{C}$ until use. Calcium lactate crystals on the surface of the blocks of full-fat Cheddar cheese were removed. The blocks were then portioned for use into 4 different products: original, full-fat cheese control; cheese for the shredded and reformed full-fat cheese; full-fat cheese used to manufacture reduced-fat cheese; and full-fat cheese that was used to produce enough removed fat for all the desired analyses. The portioned cheeses were then vacuum-packaged and kept at $6^{\circ} \mathrm{C}$ for $<2 \mathrm{wk}$ (until manufacture of the treatments).

The manufacture of the treatments was accomplished in $4 \mathrm{~d}$. On $\mathrm{d} 1$, the second portion of the first block of full-fat Cheddar cheese was shredded (Nelson and Barbano, 2004). About $1.5 \mathrm{~kg}$ of the shredded cheese were pressed into a block and then vacuum-packaged and held at $6^{\circ} \mathrm{C}$. The remaining shredded cheese was used for the fat removal process to make reduced-fat cheese. The fat was removed at $31^{\circ} \mathrm{C}$ to obtain a $50 \%$ fat reduction (Nelson and Barbano, 2004). The reducedfat cheese was also vacuum-packaged and held at $6^{\circ} \mathrm{C}$.
The fat removed was placed in a glass jar and refrigerated at $4^{\circ} \mathrm{C}$. During the second day of processing, the third portion of the first block of full-fat Cheddar cheese was used in the fat removal process (Nelson and Barbano, 2004) until about $1.2 \mathrm{~kg}$ of removed fat were produced. The fat produced on $\mathrm{d} 1$ was melted at $40^{\circ} \mathrm{C}$ in a water bath. The liquid fat from d 1 was combined with the liquid fat from $\mathrm{d} 2$, blanketed with nitrogen, and stored at $4^{\circ} \mathrm{C}$. These steps were repeated using the second full-fat block of cheese. The full-fat control cheeses, reformed full-fat cheeses, reduced-fat cheeses, and removed fat were placed in ice chests and shipped to North Carolina State University by overnight carrier. On receipt, one-half of each sample was immediately frozen at $-20^{\circ} \mathrm{C}$ for instrumental analysis; the other half was stored at $4^{\circ} \mathrm{C}$ for sensory analysis.

\section{Cheese Composition and $\mathrm{pH}$}

Fat content was determined using the Babcock method (15.8.A; Marshall, 1992). An additional $2 \mathrm{~mL}$ of Babcock acid was added to the reduced-fat cheeses for better digestion. Cheese moisture was determined gravimetrically by drying $2 \mathrm{~g}$ of cheese in a forced-air oven at $100^{\circ} \mathrm{C}$ for $24 \mathrm{~h}$ (33.2.44, 990.20; AOAC, 2000). Salt content was determined using the Volhard method (15.5.B; Marshall, 1992). The Kjeldahl method was used to determine total nitrogen (Lynch et al., 2002), pH 4.6soluble nitrogen, and 12\% TCA-soluble nitrogen (Bynum and Barbano, 1985). Crude protein was calculated by multiplying total nitrogen by 6.38 . Cheese $\mathrm{pH}$ was measured using a Xerolyt combination electrode (model HA405, Mettler Toledo, Columbus, OH) and an Accumet $\mathrm{pH}$ meter (model AR 25, Fisher Scientific, Pittsburgh, PA) after tempering to $23^{\circ} \mathrm{C}$. All analyses were performed in triplicate.

\section{Descriptive Sensory Evaluation of Cheeses and Fats}

A sensory panel $(n=14)$ evaluated the cheeses using the lexicon developed for Cheddar cheese (Drake et al., 2001). Panelists were trained for $75 \mathrm{~h}$ on aroma, tastes, and feeling factors of Cheddar cheese using the Spectrum method, including the 15-point numerical universal Spectrum intensity scale (Meilgaard et al., 1999). Full-fat, reformed full-fat, and reduced-fat cheeses were presented in 2 -cm $\times 2$-cm cubes with 3 -digit codes. Fifteen grams of cheese fat were weighed into $59-\mathrm{mL}(2-$ oz) cups, and all samples were lidded prior to sampling. During evaluation, panelists had free access to water and unsalted crackers. Cheeses and cheese fats were presented to each panelist in a randomized, balanced block design. Four cheeses or cheese fats were evalu- 
ated per tasting session. Cheeses and fats were evaluated in duplicate by each panelist according to appropriate descriptive sensory analysis practices (Meilgaard et al., 1999).

\section{Chemicals}

Ethyl ether (anhydrous, 99.8\%), sodium chloride (99\%), sodium sulfate (99\%), and 2-methyl-3-heptanone and 2-methyl pentanoic acid (internal standards for neutral/basic fraction and acidic fractions, respectively) were obtained from Aldrich Chemical Company (St. Louis, MO). Aroma compounds listed in Table 4 were provided by Aldrich Chemical Co. with the following exceptions: 1) no.13 was provided by Lancaster (Windham, $\mathrm{NH}$ ) and 2) sodium bicarbonate $(99.7 \%$, wt/wt) and hydrochloric acid $(36.5 \%$, wt/wt) were obtained from Fisher Scientific (Pittsburgh, PA).

\section{Extract Preparation and Analysis}

Direct Solvent Extraction. Cheeses and cheese fats were prepared by the methods of Milo and Reineccius (1997) with some modifications described as follows. This method of volatile compound extraction was chosen because it extracts a broad spectrum of aromaactive (flavor-contributing) compounds, including both volatile and semivolatile compounds (Singh et al., 2003). The $\mathrm{pH}$ of the cheeses (all similar and in the range of 5.1 to 5.3) and fats was not altered prior to extraction to obtain a representative sampling of volatile compounds, as they might be released from the products in the mouth. Cheese samples and cheese fats were stored frozen $\left(-20^{\circ} \mathrm{C}\right)$ and grated using a handgrater prior to extraction. Freshly grated cheese or cheese fat $(150 \mathrm{~g})$ was weighed and divided into 2 Teflon bottles (capacity $=250 \mathrm{~mL}$ ) with Tefzel closures in duplicate (300 g total for each cheese; Nalgene, Rochester, $\mathrm{NY})$. Ethyl ether ( $50 \mathrm{~mL}$ ) and $20 \mu \mathrm{L}$ of internal standard (50 $\mu \mathrm{L}$ of 2-methyl-3-heptanone and $50 \mu \mathrm{L}$ of 2-methyl pentanoic acid in $5 \mathrm{~mL}$ of methanol) were added to each bottle. The mixture was shaken for $30 \mathrm{~min}$ on a Roto mix (type 50800, Thermolyne, Dubuque, IA) at high speed. The bottles were then centrifuged at $735 \times \mathrm{g}$ for $10 \mathrm{~min}$ to separate the solvent phase from the mixture, which was subsequently collected into a glass jar. The procedure was repeated twice with $50 \mathrm{~mL}$ of ethyl ether. The solvent phases were combined and kept at $-20^{\circ} \mathrm{C}$ overnight.

Solvent-Assisted Flavor Evaporation. Volatile compounds from cheese and cheese fat extracts were distilled using solvent-assisted flavor evaporation (SAFE) (Ace Glassware, Vineland, NJ). The assembly used was similar to that described by Engel et al. (1999).
The SAFE apparatus was connected to a receiving tube and a waste tube. The glassware was then connected to a rough pump/diffusion pump as the vacuum source. The receiving tube and waste tube were held in separate Dewar flasks containing liquid nitrogen at all times. Distillation was carried out for $2 \mathrm{~h}$ under vacuum (ca. $10^{-4}$ Torr). Liquid solvent extract was loaded into the top of the SAFE apparatus and released into the vacuum drop-wise until all of the extract had been placed under vacuum conditions. The SAFE apparatus was kept thermostated at $50^{\circ} \mathrm{C}$ with a circulating water bath. After distillation, the distillate was concentrated to $20 \mathrm{~mL}$ under a stream of nitrogen gas. Concentrated distillate was then washed twice with $3 \mathrm{~mL}$ of sodium bicarbonate $(0.5 M)$ and vigorously shaken. This step raises the $\mathrm{pH}$ of the extracts to $\sim 11.0$ and helps to separate the neutral/basic compounds from the acidic compounds. The distillate was then washed 3 times with 2 $\mathrm{mL}$ of saturated sodium chloride solution to remove any residual water. After each wash step, the solution was shaken, and the upper layer (ether) containing the neutral/basic fraction was collected using a pipette. The upper (neutral/basic) layers were then pooled, and the extract was dried over anhydrous sodium sulfate and concentrated to $0.5 \mathrm{~mL}$ under a stream of nitrogen gas. Acidic volatiles were recovered by acidifying the bottom layer (aqueous phase) with hydrochloric acid (18\%) to 2 to $2.5 \mathrm{pH}$ and extracting the sample 3 times with 15 $\mathrm{mL}$ of ethyl ether. The acidified extract was dried over anhydrous sodium sulfate before concentration to 0.5 $\mathrm{mL}$ under a nitrogen gas stream.

Gas Chromatography/Olfactometry and Aroma Extract Dilution Analysis. The semiquantitative gas chromatography/olfactometry (GC/O) technique aroma extract dilution analysis (AEDA) was used to characterize aroma-active compounds contributing to flavor in cheeses and cheese fats (Grosch, 1993; Van Ruth, 2001). Aroma extract dilution analysis was performed using a HP5890 series II gas chromatograph (HewlettPackard Co., Palo Alto, CA) equipped with a flame ionization detector (FID), a sniffing port, and splitless injector was used. Both the neutral/basic and acidic fractions were analyzed from every extraction, and $2 \mu \mathrm{L}$ were injected into a polar capillary column (DB-WAX, $30 \mathrm{~m}$ length $\times 0.25 \mathrm{~mm}$ i.d. $\times 0.25-\mu \mathrm{m}$ film thickness; $\mathrm{J} \& \mathrm{~W}$ Scientific, Folson, CA) and a nonpolar column (DB-5MS, $30 \mathrm{~m}$ length $\times 0.25 \mathrm{~mm}$ i.d. $\times 0.25 \mu \mathrm{m}$ film thickness; J \& W Scientific). Column effluent was split 1:1 between the FID and the sniffing port using deactivated fused silica capillaries ( $1 \mathrm{~m}$ length $\times 0.25 \mathrm{~mm}$ i.d.). The GC oven temperature was programmed from 40 to $200^{\circ} \mathrm{C}$ at a rate of $10^{\circ} \mathrm{C} / \mathrm{min}$ with an initial hold for $3 \mathrm{~min}$ and a final hold of $20 \mathrm{~min}$. The FID and sniffing port were maintained at a temperature of $250^{\circ} \mathrm{C}$. The 
sniffing port was supplied with humidified air at 30 $\mathrm{mL} / \mathrm{min}$. The extracts were diluted stepwise with diethyl ether at a ratio of 1:3 ( $\mathrm{vol} / \mathrm{vol})$. Two experienced sniffers, each with $>50 \mathrm{~h}$ of training on GC/O, were used for AEDA. The dilution procedure was followed until sniffers detected no odorants. The highest dilution was reported as the $\log _{3}$ flavor dilution (FD) factor (Grosch, 1993).

GC/Mass Spectrometry. For GC/mass spectroscopy (GC/MS) analysis of the solvent extracts, a HP5890 Series II GC/HP 5972 mass selective detector (HewlettPackard, Co.) was used. Separations were performed on a fused silica capillary column (DB-5MS, $30 \mathrm{~m}$ length $\times 0.25 \mathrm{~mm}$ i.d. $\times 0.25 \mu \mathrm{m}$ film thickness; J\&W Scientific). Helium gas was used as a carrier at a constant flow of $1 \mathrm{~mL} / \mathrm{min}$. Oven temperature was programmed from 40 to $200^{\circ} \mathrm{C}$ at a rate of $5^{\circ} \mathrm{C} / \mathrm{min}$ with initial and final hold times of 5 and $45 \mathrm{~min}$, respectively. Mass selective detector conditions were as follows: capillary direct interface temperature, $280^{\circ} \mathrm{C}$; ionization energy, $70 \mathrm{eV}$; mass range, 33 to 330 a.m.u; scan rate, 5 scans/s. Each extract $(2 \mu \mathrm{L})$ was injected in the splitless mode. Duplicate analyses were performed on each sample. Based on MS results, relative concentrations of the compounds were calculated. The area ratio (area of internal standard:area of compound) was multiplied by the concentration of the internal standard to determine the relative abundance of the compound.

For positive identifications, retention indices (RI), mass spectra, and odor properties of unknowns were compared with those of authentic standard compounds analyzed under identical conditions. Tentative identifications were based on comparing mass spectra of unknown compounds with those in the National Institute of Standards and Technology (NIST, 1992; Gaithersburg, MD) mass spectral database or on matching the RI values and odor properties of unknowns against those of authentic standards. For the calculation of RI, an n-alkane series was used (Van den Dool and Kratz, 1963).

\section{Quantification of Odorants}

Response factors of selected compounds were calculated by direct addition of known amounts of standards to odor-free water prior to solvent extraction/SAFE. Response factors for neutral/basic compounds were determined using a 5-point standard curve $\left(\mathrm{R}^{2}>0.90\right)$ on a DB-5 column using GC/MS and for acidic, compounds were determined on a DB-WAX column using GC/FID. Using these response factors, the selected compounds were quantified using the response factor and the area ratio of compound to internal standards. Phenylacetaldehyde, ethyl butanoate, ethyl hexanoate, acetic acid, butanoic acid, and hexanoic acid were selected for quantification because of their different polarities and because preliminary AEDA data showed differences in these compounds in the different cheese/fat fractions. All standards were obtained from Aldrich Chemical Company.

\section{Consumer Evaluation of Full-Fat, Reformed Full-Fat, and Reduced-Fat Cheeses}

A second set of cheeses (18-kg block, aged 20 mo) was obtained and processed to remove the fat (Nelson and Barbano, 2004). These cheeses were then shipped to North Carolina State University, and evaluated by the trained descriptive panel using the methods described previously. Consumer testing was conducted, and fullfat, reformed full-fat, and reduced-fat cheese (all made from the same 18-kg block) were evaluated. Cheeses were cut into 2 -cm cubes and placed into $120-\mathrm{mL}$ soufflé cups with lids and 3-digit codes. The cheeses were served at $10^{\circ} \mathrm{C}$. Consumers $(\mathrm{n}=75)$ were provided with consent forms consistent with North Carolina State University human subjects approval. Cheeses were presented individually in a randomized balanced order. A screener was provided to the consumers to determine demographic information as well as their opinions about cheese and reduced-fat dairy products. Consumers indicated overall cheese acceptability, appearance liking, overall flavor liking, and texture liking using a hedonic scale $(1=$ dislike extremely to $9=$ like extremely). Consumers were also asked to rate the flavor intensity of the cheeses $(1=$ not intense to $7=$ very intense) and which sample they preferred. Consumers were provided with spring water and unsalted crackers to cleanse their palates. Panelists were rewarded with gift certificates and treats upon completion.

\section{Statistical Analyses}

Compositional, sensory, and quantification data were analyzed by ANOVA using the general linear model procedure (PROC GLM) of SAS (version 8.2, SAS Institute, Cary, NC). Following a significant $F$ statistic, means separation was conducted using Fisher's Least Significant Difference post hoc test.

\section{RESULTS AND DISCUSSION}

\section{Compositional Analysis}

The reduced-fat cheeses were reduced in fat by approximately $50 \%$ as compared with the full-fat cheeses and displayed corresponding increased moisture, protein, and salt (Table 1). In their previous research, Nelson and Barbano (2004) demonstrated that there were 
Table 1. The proximate composition of 2 original full-fat Cheddar cheeses, the shredded and reformed fullfat Cheddar cheeses, and the reduced-fat Cheddar cheeses manufactured from the full-fat cheeses using a fat removal process

\begin{tabular}{|c|c|c|c|c|c|c|c|}
\hline & Fat & Moisture & $\mathrm{CP}^{1}$ & Salt & $\begin{array}{l}\mathrm{pH} 4.6 \\
\text { SNPTN }^{2}\end{array}$ & $\begin{array}{l}12 \% \text { TCA } \\
\text { SNPTN }\end{array}$ & $\mathrm{pH}$ \\
\hline & & $\longrightarrow$ & - & & & & \\
\hline \multicolumn{8}{|l|}{ 39-mo Cheese } \\
\hline Full fat & $33.8^{\mathrm{a}}$ & $34.89^{\mathrm{b}}$ & $24.99^{\mathrm{b}}$ & $1.66^{\mathrm{b}}$ & $37.78^{\mathrm{a}}$ & $29.85^{\mathrm{a}}$ & $5.18^{\mathrm{a}}$ \\
\hline Full fat reformed & $34.0^{\mathrm{a}}$ & $34.84^{\mathrm{b}}$ & $24.94^{\mathrm{b}}$ & $1.69^{\mathrm{b}}$ & $38.05^{\mathrm{a}}$ & $30.55^{\mathrm{a}}$ & $5.21^{\mathrm{a}}$ \\
\hline Reduced fat & $17.8^{\mathrm{b}}$ & $44.03^{\mathrm{a}}$ & $30.60^{\mathrm{a}}$ & $2.06^{\mathrm{a}}$ & $38.24^{\mathrm{a}}$ & $30.29^{\mathrm{a}}$ & $5.10^{\mathrm{a}}$ \\
\hline \multicolumn{8}{|l|}{ 9-mo Cheese } \\
\hline Full fat & $33.4^{\mathrm{a}}$ & $35.15^{\mathrm{b}}$ & $24.74^{\mathrm{b}}$ & $2.11^{\mathrm{b}}$ & $29.95^{\mathrm{a}}$ & $19.85^{\mathrm{a}}$ & $5.30^{\mathrm{a}}$ \\
\hline Full fat reformed & $33.0^{\mathrm{a}}$ & $35.30^{\mathrm{b}}$ & $24.62^{\mathrm{b}}$ & $2.07^{\mathrm{b}}$ & $30.58^{\mathrm{a}}$ & $20.02^{\mathrm{a}}$ & $5.17^{\mathrm{a}}$ \\
\hline Reduced fat & $14.5^{\mathrm{b}}$ & $46.51^{\mathrm{a}}$ & $30.84^{\mathrm{a}}$ & $2.62^{\mathrm{a}}$ & $30.45^{\mathrm{a}}$ & $20.10^{\mathrm{a}}$ & $5.27^{\mathrm{a}}$ \\
\hline
\end{tabular}

more short-chain fatty acids in the cheese fat than in the full- or reduced-fat cheeses in which the fat was removed. This process of fat removal from an aged Cheddar cheese seemed to favor the partitioning of lower molecular weight triglycerides (i.e., C28 to C42) and fatty acids (C4 to C12) plus unsaturated fatty acids (C18:1 and C18:2) into the removed fat phase (Nelson and Barbano, 2004). The melting points of the cheese fat vs. reduced-fat cheeses vs. full-fat cheeses were investigated by Nelson and Barbano (2004), and they found that there were a greater number of higher melting point compounds in the reduced-fat cheese than the full-fat cheese (based on differential scanning calorimetry). Because the fat was removed at $31^{\circ} \mathrm{C}$, triacylglycerols that are liquid at this temperature are more likely to be removed with the fat, resulting in a reduced-fat cheese with relatively greater amounts of high melting point compounds.

\section{Sensory Analysis}

The aged Cheddar cheeses displayed intense cooked, milk fat/lactone, brothy, and sulfur flavors (Tables 2 and 3). The 9-mo-old cheese was characterized by spicy/ brothy and rosy/floral flavors as well as high intensities of nutty flavor. The 9-mo reformed full-fat cheese was not different from the full-fat cheese. The corresponding reduced-fat cheese had a very similar flavor profile to the full-fat cheese, with just slightly lower intensities of milk fat/lactone and rosy/floral flavor. The 9-mo-old cheese fat had very little flavor as compared with the corresponding cheeses. This cheese fat was characterized by low intensities of sulfur, spicy/brothy, rosy/floral, and nutty flavors. Results were similar in the 39-mo cheeses. This full-fat cheese also had high intensities of brothy flavor as well as low (but distinctive) intensities of catty and fruity flavors. The full-fat reformed, 39-mo cheese was not different from the full-fat cheese except in fruity flavor intensity, in which the shredded and reformed cheese had slightly lower intensities of fruity flavor. Again, the reduced-fat, 39-mo-old cheese had a very similar flavor profile to the full-fat cheese with lower intensities of milk fat/lactone and sulfur flavors. The 39-mo, reduced-fat cheese did not have detectable catty or fruity flavor. However, the cheese fat from this cheese was characterized by low intensities of sulfur, fruity, catty, and brothy flavors.

Sensory results suggest that the compounds responsible for catty, fruity, sulfur, brothy, rosy/floral, and nutty flavors are soluble in the fat fraction of cheese; therefore, these flavors are also perceived in the removed cheese fats. The lack of other sensory attributes in the removed fats suggests that the compounds responsible for milk fat/lactone and cooked/milky flavor as well as the basic tastes are retained in the aqueous phase (reduced-fat cheese) and are not present above sensory threshold in the cheese fats. One interesting case is milk fat/lactone flavor. Milk fat/lactone flavor is typically associated with milk fat. In fact, heavy cream is the food reference for this attribute (Drake et al., 2001). Lactones are formed from milk fat during heating (Badings and Neeter, 1980) and are esters of $\delta$-hydroxy fatty acids (Dimick et al., 1969). This flavor is not found in products that do not contain milk fat, such as whey protein concentrates or skim milk (Carunchia Whetstine et al., 2005b; Carunchia Whetstine and Drake, 2006). This flavor was found in the full- and reducedfat cheeses, but not in the removed cheese fat. It is important to keep in mind that the thresholds of $\gamma$ octalactone and $\delta$-decalactone (found in the cheeses) are 
Table 2. Descriptive sensory analysis of 9 -mo-old cheeses ${ }^{1}$

\begin{tabular}{|c|c|c|c|c|c|}
\hline Attribute & $\begin{array}{l}9 \mathrm{mo} ; \text { Full } \\
\text { fat }\end{array}$ & $\begin{array}{l}9 \text { mo; Full fat } \\
\text { reformed }\end{array}$ & $\begin{array}{l}9 \mathrm{mo} \text {; } \\
\text { Cheese fat }\end{array}$ & $\begin{array}{l}9 \mathrm{mo} \\
\text { Reduced fat }\end{array}$ & $\mathrm{LSD}^{2}$ \\
\hline Cooked & $2.16^{\mathrm{a}}$ & $2.25^{\mathrm{a}}$ & $\mathrm{ND}^{3}$ & $2.19^{\mathrm{a}}$ & 0.26 \\
\hline Whey & ND & ND & ND & ND & $\mathrm{NA}^{4}$ \\
\hline Diacetyl & ND & ND & ND & ND & NA \\
\hline Milk fat/lactone & $2.42^{\mathrm{a}}$ & $2.67^{\mathrm{a}}$ & ND & $1.66^{\mathrm{b}}$ & 0.39 \\
\hline Fruity & ND & ND & ND & ND & NA \\
\hline Sulfur & $2.32^{\mathrm{a}}$ & $2.10^{\mathrm{a}}$ & $0.53^{\mathrm{b}}$ & $2.22^{\mathrm{a}}$ & 0.29 \\
\hline Free fatty acid & ND & ND & ND & ND & NA \\
\hline Brothy & $3.74^{\mathrm{a}}$ & $3.75^{\mathrm{a}}$ & $2.75^{\mathrm{b}}$ & $3.73^{\mathrm{a}}$ & 0.38 \\
\hline Rosy/floral & $2.50^{\mathrm{a}}$ & $2.43^{\mathrm{a}}$ & $1.02^{\mathrm{b}}$ & $1.13^{\mathrm{b}}$ & 0.33 \\
\hline Nutty & $2.12^{\mathrm{a}}$ & $2.10^{\mathrm{a}}$ & $1.72^{\mathrm{b}}$ & $2.38^{\mathrm{a}}$ & 0.36 \\
\hline Catty & ND & ND & ND & ND & NA \\
\hline Sour & $3.37^{\mathrm{a}}$ & $3.35^{\mathrm{a}}$ & ND & $3.48^{\mathrm{a}}$ & 0.28 \\
\hline Sweet & $3.00^{\mathrm{a}}$ & $3.03^{\mathrm{a}}$ & ND & $3.08^{\mathrm{a}}$ & 0.32 \\
\hline Salty & $4.43^{\mathrm{b}}$ & $4.40^{\mathrm{b}}$ & ND & $4.85^{\mathrm{a}}$ & 0.37 \\
\hline Bitter & $0.50^{\mathrm{a}}$ & $0.50^{\mathrm{a}}$ & ND & $0.53^{\mathrm{a}}$ & 0.22 \\
\hline Umami & $2.39^{\mathrm{a}}$ & $2.56^{\mathrm{a}}$ & ND & $2.55^{\mathrm{a}}$ & 0.35 \\
\hline
\end{tabular}

${ }^{\mathrm{a}, \mathrm{b}}$ Means in a row followed by different letters are different $(P<0.05)$.

${ }^{1}$ Intensities are scored on the 15 -point universal intensity Spectrum scale where $0=$ none to $15=$ very high (Meilgaard et al., 1999; Drake et al., 2001).

${ }^{2} \mathrm{LSD}=$ Least significant difference.

${ }^{3} \mathrm{ND}=$ Not detected.

${ }^{4} \mathrm{NA}=$ Not applicable.

10 times higher in oil than in water (Rychlik et al., 1998). This may be an explanation why milk fat/lactone flavor is not detected in the cheese fat but is detected in the cheeses.

As expected, there were few differences in basic tastes between the full-fat and reduced-fat cheeses. The salt content of the reduced-fat cheeses was higher; therefore, it is logical that the reduced-fat cheeses were salt- ier than the full-fat cheeses $(P<0.05)$. Higher salt content in reduced-fat cheeses was also observed by Nelson and Barbano (2004). The cheese fats did not have any basic tastes. Because the elicitation of these basic tastes is based on the interaction of water-soluble compounds (sugars, salts, etc.) with the saliva (Meilgaard et al., 1999), it is expected that there would be no basic tastes in the fat fractions.

Table 3. Descriptive sensory analysis of 39 -mo-old cheeses ${ }^{1}$

\begin{tabular}{|c|c|c|c|c|c|}
\hline Attribute & $\begin{array}{l}39 \text { mo; Full } \\
\text { fat }\end{array}$ & $\begin{array}{l}39 \text { mo; Full fat } \\
\text { reformed }\end{array}$ & $\begin{array}{l}39 \mathrm{mo} ; \\
\text { Cheese fat }\end{array}$ & $\begin{array}{l}39 \mathrm{mo} \\
\text { Reduced fat }\end{array}$ & $\mathrm{LSD}^{2}$ \\
\hline Cooked & $2.41^{\mathrm{ab}}$ & $2.59^{\mathrm{a}}$ & $\mathrm{ND}^{3}$ & $2.18^{b}$ & 0.27 \\
\hline Whey & ND & ND & ND & ND & $\mathrm{NA}^{4}$ \\
\hline Diacetyl & ND & ND & ND & ND & NA \\
\hline Milk fat/lactone & $2.59^{\mathrm{a}}$ & $2.48^{\mathrm{a}}$ & ND & $1.74^{\mathrm{b}}$ & 0.34 \\
\hline Fruity & $1.17^{\mathrm{b}}$ & $0.70^{\mathrm{b}}$ & $1.76^{\mathrm{a}}$ & ND & 0.54 \\
\hline Sulfur & $2.11^{\mathrm{a}}$ & $1.97^{\mathrm{a}}$ & $0.50^{\mathrm{b}}$ & $1.97^{\mathrm{a}}$ & 0.30 \\
\hline Free fatty acid & ND & ND & ND & ND & NA \\
\hline Brothy & $3.05^{\mathrm{a}}$ & $2.85^{\mathrm{a}}$ & $1.29^{\mathrm{b}}$ & $2.93^{\mathrm{a}}$ & 0.40 \\
\hline Rosy/floral & ND & ND & ND & ND & NA \\
\hline Nutty & $1.31^{\mathrm{ab}}$ & $0.88^{\mathrm{b}}$ & $1.47^{\mathrm{a}}$ & $1.38^{\mathrm{a}}$ & 0.47 \\
\hline Catty & $0.80^{\mathrm{a}}$ & ND & $0.90^{\mathrm{a}}$ & ND & 0.27 \\
\hline Sour & $3.25^{\mathrm{a}}$ & $3.00^{\mathrm{a}}$ & ND & $3.13^{\mathrm{a}}$ & 0.23 \\
\hline Sweet & $2.54^{\mathrm{a}}$ & $2.63^{\mathrm{a}}$ & ND & $2.60^{\mathrm{a}}$ & 0.27 \\
\hline Salty & $4.06^{\mathrm{b}}$ & $3.93^{\mathrm{b}}$ & ND & $4.65^{\mathrm{a}}$ & 0.30 \\
\hline Bitter & ND & ND & ND & ND & NA \\
\hline Umami & $2.72^{\mathrm{a}}$ & $2.56^{\mathrm{ab}}$ & ND & $2.31^{\mathrm{b}}$ & 0.26 \\
\hline
\end{tabular}

${ }^{\mathrm{a}, \mathrm{b}}$ Means in a row followed by different letters are different $(P<0.05)$.

${ }^{1}$ Intensities are scored on the 15 -point universal intensity Spectrum scale where $0=$ none to $15=$ very high (Meilgaard et al., 1999; Drake et al., 2001).

${ }^{2} \mathrm{LSD}=$ Least significant difference.

${ }^{3} \mathrm{ND}=$ Not detected.

${ }^{4} \mathrm{NA}=$ Not applicable. 


\section{GC/O and Compound Quantification}

Thirty-three aroma-active compounds with a $\log _{3}$ FD factor $>1$ were identified in these aged cheeses. All of these compounds have been previously reported in dairy products (Karagul-Yüceer et al., 2002, 2003; Singh et al., 2003; Carunchia Whetstine et al., 2005a, b). The aroma-active compounds found in the full-fat and reduced-fat cheeses as well as the cheese fats are listed in Table 4. It is important to keep in mind that AEDA is a semiquantitative technique; therefore, the values do not represent actual concentrations of compounds, only their aroma activity in the extracts. As such, AEDA results provide a snapshot or profile of the most potent aroma- (flavor-) contributing compounds in a given extracted sample (full- and reduced-fat cheeses, removed cheese fat) (Audouin et al., 2001). $\log _{3}$ FD factors for the same compound differing by $\geq 2 \log _{3}$ are considered suggestive of concentration differences. In the full- and reduced-fat cheeses, the $\log _{3}$ FD values were similar for most compounds. This is consistent with both the sensory results and previously reported data by Nelson and Barbano (2004).

Aroma extract dilution analysis $\log _{3} \mathrm{FD}$ values are semiquantitative and based on aroma perception, which is not necessarily linearly related to concentration for a given compound. Therefore, caution must be taken when evaluating the AEDA data relative to concentration. As such, several compounds were selected for further examination and quantification (Tables 5 and 6) based on their consistent large differences in $\log _{3}$ FD factors (Table 4) between the full- and reducedfat cheeses and the removed cheese fats and if the compounds were within instrumental linear detection range. Esters contribute to fruity flavor in Cheddar cheese (Singh et al., 2003). This flavor was distinctive in the 39-mo cheeses and cheese fat (Table 3). The cheese fats contained higher concentrations of ethyl butanoate and ethyl hexanoate than either of the fullfat cheeses (Tables 5 and 6), and this contributed to their fruity aromas. Landy et al. (1998) concluded that esters were not retained at the lipid-aqueous phase in protein/water/lipid model systems, and this is why they likely were removed from the cheese with the fat. Other nonpolar compounds were retained by the aqueous phase. Ethyl hexanoate also is more volatile and soluble in fat when the lipid is above its melting point (Roudnitzky et al., 2002; Roberts et al., 2003b; Relkin et al., 2004). Because most of the cheese fat was liquid during fat removal $\left(31^{\circ} \mathrm{C}\right)$ (Nelson and Barbano, 2004), ethyl hexanoate would have been more soluble and, therefore, more likely to be removed with the fat (as observed).

Phenylacetaldehyde was quantified because the 9mo cheese displayed rosy/floral brothy notes and phen- ylacetaldehyde is a main cause of rosy/floral flavor, a distinct off-flavor in aged Cheddar cheeses (Carunchia Whetstine et al., 2005a). The $\log _{3}$ FD factor of this compound was highest in the 9-mo full-fat cheese but was much lower in the reduced-fat and cheese fat fractions (Table 4). The same trend was observed in the quantification of this compound (Tables 5 and 6). The full-fat cheese had a much higher concentration of phenylacetaldehyde than either the reduced-fat cheese or cheese fat. The threshold of phenylacetaldehyde in water is 2 ppb (Carunchia Whetstine et al., 2005a) but is likely much higher than that in cheese and in pure fat. Fat content is important for flavor release. Perhaps phenylacetaldehyde is partitioning equally into both the reduced-fat cheese and cheese fat but is present near sensory threshold concentrations in cheese. This would explain why the sensory, AEDA, and quantification results show lower intensities and concentrations of phenylacetaldehyde (rosy/floral) in the reduced-fat cheese and cheese fat compared with the full-fat cheese.

Acetic acid, butanoic acid, and hexanoic acid were identified by AEDA. Previous research with Cheddar cheese has also documented high FD factors (by AEDA) for these fatty acids in both full- and reduced-fat Cheddar cheese (Christensen and Reineccius, 1995; Milo and Reineccius, 1997). The AEDA values for acetic acid were consistently lower in cheese fats than in full- or reduced-fat cheeses; results for butanoic and hexanoic were not consistent. Acetic acid is more polar than either butanoic or hexanoic acid and, therefore, more likely to remain in the polar cheese aqueous phase. Based on the initial AEDA results, these fatty acids (acetic, butanoic, and hexanoic) were quantified. Similar to AEDA results, acetic acid was found in lower concentrations in cheese fats than in cheeses, and there were no clear trends in the partitioning of butanoic and hexanoic acids (Tables 5 and 6).

\section{Flavor Release}

Flavor and flavor release are very complicated. There are several mechanisms that may be responsible for these reactions such as mass transfer, matrix structural hindrance, flavor-matrix interactions, etc. (Seuvre et al., 2000). Additionally, each flavor compound has different physical and chemical properties. Only compounds that are present in high enough concentrations to stimulate the olfactory receptors (above threshold) can have a direct impact on flavor (Delahunty et al., 1996). There are several factors that influence flavor thresholds, including concentration in the cheese, composition and structure of the cheese, the compound placement in the cheese (free as a gas, dissolved in water or dissolved in fat, insoluble as a salt, or bound 
Table 4. Potent odorants in full-fat, reduced-fat, and cheese fat in 9- and 39-mo-old cheeses

$\mathrm{RI}^{2}$

$\mathrm{RI}^{2}$

\begin{tabular}{|c|c|c|c|c|c|c|c|}
\hline & \multirow[b]{2}{*}{ Compound } & \multirow[b]{2}{*}{ Fraction } & \multirow[b]{2}{*}{ Odor $^{1}$} & \\
\hline No. & & & & DB-5 & $\begin{array}{l}\text { DB- } \\
\text { Wax }\end{array}$ & $\begin{array}{l}39 \text { mo; } \\
\text { Full fat }\end{array}$ & $\begin{array}{l}39 \mathrm{mo} \\
\text { fat }\end{array}$ \\
\hline
\end{tabular}

Acetic acid

Diacetyl

Ethyl butanoate

2-methyl thiophene

Propyl butyrate

Hexanal

(Z)-4-heptenal

Methional

2-methyl-3-fuanthiol

Dimethyl trisulfide

1-octen-3-one

Ethyl hexanoate

Octanal

2-acetylthiazole

Hexanoic acid

Phenylacetaldehyde

2-isopropyl-3-

methoxypyrazine

Nonanal

2-acetyl-2-thiazoline

(E,E)-2,4-octadienal

2-phenethanol

4-hydroxy-2,5-

dimethyl-3(2H)-

Ac Vinega

NB Buttery

$\begin{array}{ll}\text { NB } & \text { Fruity } \\ \text { NB } & \text { Plastic bottle } \\ \text { NB } & \text { Fruity }\end{array}$

Fruity

NB

Rancid cheese

Doughy/fatty

Potato

Cooked/brothy

Cabbage/sulfur

Fruity

Citrus
Nutty

Sweaty

Rosy

$\begin{array}{ll}\text { Rosy } & 1,051 \\ \text { Bell pepper/geranium } & 1,080\end{array}$

Wax

5

fat $\quad$ Red

furanone (Furaneol ${ }^{\mathrm{TM}}$ )

(E Z)-2 6-nonadienal

(E)-2-nonenal

Unknown

4,5-dimethyl-3-

hydroxy-2-(5H)-
furanone (sotolon)

$\delta$-octalactone

4-methyl octanoic acid

(E,E)-2,4-decadienal

$\delta$-decalactone

Fatty/floral

Popcorn

Fatty/green

Sweet/floral

$\begin{array}{rrr}700 & 1,479 & 5 \\ 688 & 998 & 4\end{array}$

$\begin{array}{lll}776 & 1,092 & 2 \\ 787 & 1,165 & <1\end{array}$

$787 \quad 1,165$

$796 \quad 1,215$

$853 \quad$ ND

$850 \quad 1,663 \quad 9$

903

$932 \quad 1,513 \quad$ ND

1,372

$973 \quad 1,450$

1,450

$\begin{array}{ll}987 & 1,369 \\ 996 & 1,221\end{array}$

996
1,005

$1,008 \quad 1,273$

1,273
1,854

1,413

$\begin{array}{cc}4 & 5 \\ \text { ND } & 2\end{array}$

$\log _{3}$ FD Factor ${ }^{3}$

$39 \mathrm{mo} ; \quad 9 \mathrm{mo} ; \quad 9 \mathrm{mo} ; \quad 9 \mathrm{mo}$

Red fat $\quad$ Full fat $\quad 9 \mathrm{mo} ; \quad 9 \mathrm{mo}$

Method of

Red fat Full fat Fat $\quad$ Red fat identification ${ }^{4}$

$\gamma$-octalacton

Cucumber

Fatty/old books

Bell pepper

Curry/maple/spicy

1,100

3

ND $\quad$ ND

$\begin{array}{ccccc}6 & 4 & 3 & 5 & \text { RI, odor, MS } \\ 5 & 2 & 2 & 4 & \text { RI, odor, MS } \\ 1 & 1 & \text { ND } & \text { ND } & \text { RI, odor, MS }\end{array}$

1

1

7
ND
4

$4 \quad$ ND

ND

42

1

2
2

4

ND

$\begin{array}{lcl}4 & 1 & \text { RI, odor, } \\ 3 & 2 & \text { RI, odor }\end{array}$

$\begin{array}{lll}3 & 2 & \text { RI, odor, MS }\end{array}$

RI, odor, MS

RI, odor, MS

RI, odor

RI, odor, MS

RI, odor

RI, odor

$\mathrm{RI}$, odor

RI, odor, MS
RI, odor, MS

RI, odor

RI, odor, MS

RI, odor,
RI, odor

RI, odor, MS

RI, odor

RI, odor

RI, odor
RI, odor

$\begin{array}{lll}1,116 & & 3 \\ 1,135 & & 1 \\ 1,159 & 2,224 & 5\end{array}$

ND

2
2
3

ND

1
3
4

2
$<1$
$<1$
2

$\begin{array}{cc}4 & 4 \\ \mathrm{ND} & \mathrm{ND}\end{array}$

RI, odor

$\begin{array}{llccccccl}1,160 & & \text { ND } & \text { ND } & \text { ND } & 4 & 5 & 4 & \text { RI, odor } \\ 1,168 & 1,569 & 3 & 2 & 2 & 2 & 3 & 5 & \text { RI, odor, MS }\end{array}$

1,168

1,174

$2,368 \quad \mathrm{ND}$

ND

ND

Odor

\begin{tabular}{|c|c|c|c|c|c|c|c|c|c|}
\hline Coconut & 1,287 & & ND & ND & ND & $<1$ & 5 & 4 & RI, odor, MS \\
\hline Waxy/animal & 1,528 & 2,097 & 3 & $<1$ & ND & $<1$ & $<1$ & $<1$ & RI, odor \\
\hline Tatty & 1,325 & & ND & ND & ND & 3 & 5 & 5 & RI, odor, MS \\
\hline Peach & 1,431 & & 1 & ND & 1 & ND & 2 & 4 & RI, odor, MS \\
\hline Coconu & 1,508 & & $<1$ & ND & 2 & 2 & 4 & 2 & RI, odor \\
\hline
\end{tabular}

${ }^{1}$ Odor description at the gas chromatography-sniffing port.

${ }^{2} \mathrm{RI}=$ Retention indices; calculated from gas chromatography/olfactory data.

${ }^{3} \mathrm{FD}=$ Flavor dilution; factors were determined on a DB-5 column for neutral/basic compounds and on a DB-Wax column for acidic compounds.

${ }^{4}$ Compounds were identified by comparison with the authentic standards on the following criteria: RI on DB-Wax and DB-5MS columns, odor property at the gas chromatography-sniffing port, and mass spectra in the electron impact mode. 
Table 5. Quantification and sensory orthonasal threshold values of selected compounds in 9-mo-old cheeses

\begin{tabular}{|c|c|c|c|c|c|c|}
\hline \multirow[b]{2}{*}{ Compound } & \multirow[b]{2}{*}{ RI } & \multicolumn{3}{|c|}{ Concentration ppm $(\mu \mathrm{g} / \mathrm{g})$} & \multirow[b]{2}{*}{ LSD } & \multirow[b]{2}{*}{$\begin{array}{l}\text { Reported } \\
\text { threshold } \\
\text { (ppm) }\end{array}$} \\
\hline & & $\begin{array}{l}9 \text { mo } \\
\text { full } \\
\text { fat }\end{array}$ & $\begin{array}{l}9 \text { mo } \\
\text { cheese } \\
\text { fat }\end{array}$ & $\begin{array}{l}9 \text { mo } \\
\text { reduced } \\
\text { fat }\end{array}$ & & \\
\hline Acetic acid & $700^{1}$ & $785^{\mathrm{a}}$ & $201^{\mathrm{b}}$ & $423^{\mathrm{ab}}$ & 406 & $36^{3}$ \\
\hline Butanoic acid & $850^{1}$ & $515^{\mathrm{a}}$ & $191^{\mathrm{b}}$ & $520^{\mathrm{a}}$ & 225 & $0.86^{3}$ \\
\hline \multirow[t]{2}{*}{ Hexanoic acid } & $1,008^{1}$ & $28^{\mathrm{a}}$ & $15^{\mathrm{a}}$ & $17^{\mathrm{a}}$ & 21 & $2.8^{3}$ \\
\hline & & \multicolumn{3}{|c|}{ Concentration ppb (ng/g) } & & (ppb) \\
\hline Ethyl butanoate & $776^{2}$ & $\mathrm{ND}^{4}$ & $0.3^{\mathrm{a}}$ & ND & 0.8 & $4.7^{3}$ \\
\hline Ethyl hexanoate & $996^{2}$ & $3.9^{\mathrm{b}}$ & $11.6^{\mathrm{a}}$ & $1.8^{\mathrm{b}}$ & 1.9 & $1.7^{3}$ \\
\hline Phenylacetaldehyde & $1,051^{2}$ & $30.3^{\mathrm{a}}$ & $3.3^{\mathrm{b}}$ & $8.7^{\mathrm{ab}}$ & 39.4 & $2^{5}$ \\
\hline
\end{tabular}

${ }^{\mathrm{a}, \mathrm{b}}$ Means in a row with different superscript letters are different $(P<0.05)$.

${ }^{1}$ Retention index (RI) calculated from flame ionization detector results on a DB-Wax column.

${ }^{2}$ Retention indices calculated from mass spectrometry (MS) results on a DB-5MS column.

${ }^{3}$ Thresholds were reported orthonasally in water by Rychlik et al. (1998).

${ }^{4} \mathrm{ND}=$ Not detected.

${ }^{5}$ Thresholds were reported orthonasally in water by Carunchia Whetstine et al. (2005a).

to protein), the extent of structure destruction during chewing, and the temperature and airflow around the cheese in the mouth (Delahunty et al., 1996). All of this must be kept in mind when analyzing the impact of compounds on flavor.

Fat content is also important for flavor release. Flavor release is different in the mouth in reduced-fat products than in full-fat products because the composition (fat, water) can affect sensory thresholds. Hydrophobic compounds have a lower vapor pressure and a higher sensory threshold in oil than in water (Relkin et al., 2004). When fat is present, hydrophobic flavor compounds are bound to the fat molecules by Van der Walls and hydrophobic interactions (Plug and Haring, 1993). Therefore, there are fewere of these hydrophobic flavor compounds in the headspace, and sensory thresholds are increased. In foods with lower fat content, the flavor molecules are not soluble to the same extent as in higher fat food, increasing flavor release (Plug and Haring, 1993). Roberts et al. (2003a) found that the release of volatile flavor compounds (both ortho- and retronasal) was greater when there was less fat present in water and milks with various fat contents. Prindiville et al. (1999, 2000) showed that perceived cocoa intensity (at the same concentration) was higher in reduced-fat chocolate ice cream than in full-fat ice cream, and $\mathrm{Li}$ et al. (1997) found similar results in vanilla intensity in vanilla ice cream. These studies suggest that if the flavor compounds are hydrophobic and present in a reduced-fat environment, the flavor intensities are increased. In the current study, the reduced-fat cheese has a higher water:fat ratio than the full-fat cheese;

Table 6. Quantification and sensory orthonasal threshold values of selected compounds in 39-mo-old cheeses

\begin{tabular}{|c|c|c|c|c|c|c|}
\hline \multirow[b]{2}{*}{ Compound } & \multirow[b]{2}{*}{ RI } & \multicolumn{3}{|c|}{ Concentration ppm $(\mu \mathrm{g} / \mathrm{g})$} & \multirow[b]{2}{*}{ LSD } & \multirow[b]{2}{*}{$\begin{array}{l}\text { Reported } \\
\text { threshold } \\
\text { (ppm) }\end{array}$} \\
\hline & & $\begin{array}{l}9 \text { mo } \\
\text { full } \\
\text { fat }\end{array}$ & $\begin{array}{l}9 \text { mo } \\
\text { cheese } \\
\text { fat }\end{array}$ & $\begin{array}{l}9 \text { mo } \\
\text { reduced } \\
\text { fat }\end{array}$ & & \\
\hline Acetic acid & $700^{1}$ & $1,560^{\mathrm{a}}$ & $244^{\mathrm{b}}$ & $1,589^{\mathrm{a}}$ & 262 & $36^{3}$ \\
\hline Butanoic acid & $850^{1}$ & $727^{\mathrm{a}}$ & $746^{\mathrm{a}}$ & $1,093^{\mathrm{a}}$ & 538 & $0.86^{3}$ \\
\hline \multirow[t]{2}{*}{ Hexanoic acid } & $1,008^{1}$ & $38^{\mathrm{b}}$ & $61^{\mathrm{a}}$ & $36^{\mathrm{b}}$ & 11 & $2.8^{3}$ \\
\hline & & \multicolumn{3}{|c|}{ Concentration ppb (ng/g) } & & $(\mathrm{ppb})$ \\
\hline Ethyl butanoate & $776^{2}$ & $19.3^{\mathrm{b}}$ & $67.4^{\mathrm{a}}$ & $5.4^{\mathrm{b}}$ & 27.0 & $4.7^{3}$ \\
\hline Ethyl hexanoate & $996^{2}$ & $7.8^{\mathrm{b}}$ & $24.6^{\mathrm{a}}$ & $4.1^{\mathrm{b}}$ & 6.4 & $1.7^{3}$ \\
\hline Phenylacetaldehyde & $1,051^{2}$ & $2.1^{\mathrm{b}}$ & $4.1^{\mathrm{ab}}$ & $6.3^{\mathrm{a}}$ & 3.8 & $2^{4}$ \\
\hline
\end{tabular}

\footnotetext{
${ }^{\mathrm{a}, \mathrm{b}}$ Means in a row with different superscript letters are different $(P<0.05)$.

${ }^{1}$ Retention index (RI) calculated from flame ionization detector results on a DB-Wax column.

${ }^{2}$ Retention indices calculated from mass spectrometry (MS) results on a DB-5MS column.

${ }^{3}$ Thresholds were reported orthonasally in water by Rychlik et al. (1998).

${ }^{4}$ Thresholds were reported orthonasally in water by Carunchia Whetstine et al. (2005a).
} 
therefore, it is likely that the sensory thresholds for flavor compounds are lower in the reduced-fat cheese than in the cheese fat or full-fat cheese. This means lower concentrations of flavor volatiles are needed to elicit the same sensory response in the reduced-fat cheeses. Most flavor compounds are hydrophobic (more fat soluble, thresholds in oil are increased), and this phenomenon can explain why the cheese fats had much less intense flavors than the cheeses even though the concentrations of flavor compounds were not always less (Tables 5 and 6).

There are 3 fractions of the cheese (the fat phase, aqueous phase, and the protein matrix), and each can impact flavor release. The protein matrix of the cheese may bind compounds and retain them during the physical removal of the cheese fat. However, compounds that are protein-bound may not be released in the mouth, and although their concentration can be measured analytically, they may have no flavor impact during consumption of the cheese. The presence of proteins can have dramatic effects on the retention of flavor compounds (Seuvre et al., 2000). Casein has distinct polar and hydrophobic regions (Swaisgood, 1996), which can act as binding sites for different flavor compounds (Cometto-Muniz, 1981).

Several studies have documented the importance of the water-soluble fractions (WSF) in the flavor of cheese (Salles et al., 2000; Taborda et al., 2003). Although many of the volatile compounds in cheese are nonpolar, it is likely that some volatile compounds are present in the WSF (Taborda et al., 2003). The WSF contains amino acids, peptides, mineral salts, lactic acid, and lactose, which are precursors to many flavor compounds as well as some volatile compounds (Taborda et al., 2003), such as short-chain free fatty acids, aldehydes, esters, and alcohols. By weight, the majority of the compounds present in the WSF are nonvolatile. These compounds contribute to both volatile and nonvolatile (basic taste) flavor production during cheese aging via the breakdown of amino acids and (to a lesser extent) glycolysis. There are volatile compounds present in the WSF as well. Engels et al. (1997) found that there were many volatile compounds found in the WSF including fatty acids, esters, alcohols, ketones, sulfur compounds, and aldehydes. Aldehydes were the most prevalent, and these compounds have low aroma thresholds and contribute to flavor (Hall and Andersson, 1985). Therefore, WSF contribute to flavor both directly and indirectly. There is a higher percentage of the original WSF from the full-fat cheese per serving in a reduced-fat cheese made by the fat process of Nelson and Barbano (2004) than in a serving of original full-fat cheese.

It has been typically thought that flavor compounds are mostly hydrophobic and that the fat phase contri- butes greatly to flavor. However, this study demonstrates that the aqueous phase retains these nonpolar flavor compounds during fat removal. When the cheese is made, the curd temperature is 32 to $38^{\circ} \mathrm{C}$, and most of the fat is liquid. As the curd is formed into blocks, it begins to cool, and the highest molecular weight triacylglycerols begin to solidify. As the temperature continues to decrease, the bulk of the milk fat in these isolated areas supercools. When the fat becomes solid, it forms an amorphous solid and remains that way during cheese aging $\left(5.5\right.$ to $\left.8^{\circ} \mathrm{C}\right)$. Although there may be some isolated areas of liquid fat within each localized fat deposit, it likely that this liquid fat will be surrounded by solid fat. The solid fat will have little capability to interact and equilibrate with anything in the aqueous phase of Cheddar cheese during aging. This has been observed with the solubility of flavor compounds such as esters, diacetyl, and lactones. These compounds are more soluble in liquid milk fat than in solid milk fat (Relkin et al., 2004). It appears that the water phase is where most of the flavor reactions occur. During aging, most of the reactions that create flavor compounds are enzymatic and take place in the aqueous phase (McSweeney and Fox, 2004; Upadhyay et al., 2004). It is likely that there is very little movement of compounds from the water phase into the fat phase at typical Cheddar cheese aging temperatures. Therefore, the fat itself has very little flavor or very few flavor compounds. This is indeed what was observed in the present study.

Biochemical reactions (glycolysis, proteolysis, lipolysis) occur in the water phase of full-fat and reduced-fat cheeses (Milo and Reineccius, 1997; Singh et al., 2003), and this is why reduced-fat cheeses made from skim milk do not display a complete lack of flavor. These cheeses, however, do not have characteristic Cheddar flavor (Drake and Swanson, 1995; Milo and Reineccius, 1997; Suriyaphan et al., 1999). The biochemical parameters have shifted prior to aging in reduced-fat cheeses that are made by removing fat from the milk because the moisture and fat contents are different than in fullfat cheeses and the composition of the aqueous phase of the cheese is different (Johnson and Chen, 1995). Therefore, different types and concentrations of compounds (and consequently flavors) form in the higher moisture/lower salt in moisture/lower fat microenvironment of reduced-fat cheese (Johnson and Chen, 1995; Milo and Reineccius, 1997). Clearly fat is necessary for characteristic Cheddar flavor formation and perception (Law et al., 1972; Drake and Swanson, 1995; Milo and Reineccius, 1997).

\section{Consumer Evaluation}

Both descriptive sensory analysis and instrumental analysis indicate that flavor is retained in reduced-fat 
Table 7. Consumer evaluation of full-fat, full-fat reformed, and reduced-fat cheeses $(\mathrm{n}=75)$

\begin{tabular}{lllll}
\hline Attribute & $\begin{array}{l}\text { Full fat } \\
\text { (control) }\end{array}$ & $\begin{array}{l}\text { Full fat } \\
\text { reformed }\end{array}$ & $\begin{array}{l}\text { Reduced } \\
\text { fat }\end{array}$ & LSD $^{1}$ \\
\hline Appearance liking $^{2}$ & $6.93^{\mathrm{a}}$ & $6.81^{\mathrm{a}}$ & $6.74^{\mathrm{a}}$ & 0.35 \\
Flavor liking $^{\mathrm{a}}$ & $7.23^{\mathrm{a}}$ & $6.65^{\mathrm{b}}$ & $6.09^{\mathrm{c}}$ & 0.51 \\
Texture liking $^{2}$ & $7.28^{\mathrm{a}}$ & $6.50^{\mathrm{b}}$ & $5.15^{\mathrm{c}}$ & 0.52 \\
Overall acceptability $^{2}$ & $7.19^{\mathrm{a}}$ & $6.52^{\mathrm{b}}$ & $5.77^{\mathrm{c}}$ & 0.47 \\
Flavor intensity $^{\mathrm{a}}$ & $4.46^{\mathrm{a}}$ & $4.78^{\mathrm{a}}$ & $4.72^{\mathrm{a}}$ & 0.34 \\
\hline
\end{tabular}

${ }^{\mathrm{a}-\mathrm{c}}$ Means in a row followed by different letters are different $(P<$ $0.05)$.

${ }^{1} \mathrm{LSD}=$ Least significant difference.

${ }^{2} \mathrm{~A}$ 9-point hedonic scale was used, where 1 = dislike extremely to $1=$ like extremely.

${ }^{3} \mathrm{~A} 7$-point scale was used, where $1=$ not intense to $7=$ very intense.

cheeses made from this novel fat-removal process. However, it is also important to understand consumer perception of cheeses made with this process. Therefore, another set of cheeses (full fat, full-fat reformed, and reduced-fat) was obtained from Cornell University for the purpose of conducting consumer acceptability testing. Prior to consumer testing, it was determined that the proximate composition of these cheeses was similar to the previous cheeses (data not shown). Descriptive sensory analysis was also conducted on these cheeses prior to consumer evaluation, and the flavor profiles were similar to the 9-mo cheeses evaluated in the initial experiment. Cheeses were characterized by brothy, sulfur, and nutty flavors. As observed in the previously analyzed cheeses, there were no differences in the flavor of full-fat and full-fat reformed cheeses $(P>0.05)$, and the reduced-fat cheese had lower intensities of nutty and milk fat/lactone flavors $(P<0.05$; data not shown).

The seventy-five consumers that evaluated the cheeses were heavy consumers of Cheddar cheese. Fifty-six percent consumed Cheddar cheese at least once weekly, and $28 \%$ consumed Cheddar cheese $\geq 2$ times/wk. Most (79\%) consumed sharp Cheddar cheese. There were no differences in the overall appearance liking of the 3 treatments $(P>0.05$; Table 7$)$. The flavor intensity of all of the cheeses was also not different $(P$ $>0.05$ ). However, there were differences in flavor liking $(P<0.05)$ among all cheeses, including the full-fat control and full-fat reformed cheeses. This is interesting because the descriptive panel did not find any differences in the flavor profile of the full-fat control and the reformed full-fat cheeses. Texture liking of the reformed full-fat cheese was lower than the full-fat cheese (Table 7). It is likely that texture contributed to the decrease in flavor liking of the reformed full-fat cheese. The overall acceptability of the full-fat control cheese was very high (7.2 on a 9-point scale). The reformed cheeses (both full and reduced fat) were significantly lower in overall acceptability, although still liked (5.8 to 6.5 on a 9point scale). Based on consumer texture liking results, texture likely plays a major role in the lower acceptability of these reformed cheeses. The texture of the fullfat reformed cheese was more liked than the reducedfat cheese texture. Even though both of these cheeses were reformed and had similar textures, the presence of fat improves texture and mouthfeel and may contribute to the difference in texture liking. More than 50\% of consumers wrote negative comments regarding the texture of the reformed full- and reduced-fat cheeses, and the texture of these cheeses should be investigated further in future work.

These results also indicate that the novel fat removal process developed by Nelson and Barbano (2004) is successful in removing $50 \%$ of the fat and retaining characteristic aged Cheddar cheese flavor. It is important also to note that consumers were given no information about the cheeses and were not informed that some of the cheeses were reduced in fat. One can hypothesize, given the flavor intensity results, that if reduced-fat cheeses made by this novel fat removal process were tested by consumers in conjunction with traditional reduced-fat cheese made from low fat milk, the reduced-fat cheeses in the current study would score significantly higher in flavor liking and intensity because of the lack of characteristic Cheddar flavor found in most reducedfat cheese.

\section{CONCLUSIONS}

The fractionation of aroma compounds in food matrices is dependent on many different variables including the physical and chemical properties of the compounds and the microstructure of the matrix. This study demonstrated that aged Cheddar cheeses can successfully have the fat partially removed and maintain the flavor character of the original full-fat cheese. This is a positive step in providing consumers with an intensely flavored, lower fat alternative to full-fat aged Cheddar cheese.

\section{ACKNOWLEDGMENTS}

Funding provided in part by the California Dairy Research Foundation, the Northeast Dairy Foods Research Center, and Dairy Management, Inc. Manuscript FSR 05-33 of the Dept. of Food Science, North Carolina State University.

\section{REFERENCES}

Association of Official Analytical Chemists. 2000. Official Methods of Analysis. 17th ed. Assoc. Off. Anal. Chem., Gaithersburg, MD. Audouin, V., F. Bonnet, Z. M. Vickers, and G. A. Reineccius. 2001. Limitations in the use of odor activity values to determine im- 
portant odorants in foods. Pages 156-171 in Gas Chromatography-Olfactometry: The State of the Art. ACS Symposium Series No. 782. Am. Chem. Soc., Washington, DC.

Badings, H. T., and R. Neeter. 1980. Recent advances in the study of aroma compounds of milk and dairy products. Neth. Milk Dairy J. 34:9-30.

Bryant, A., Z. Ustunol, and J. Steffe. 1995. Texture of Cheddar cheese as influenced by fat reduction. J. Food Sci. 60:1216-1219, 1236.

Bynum, D. G., and D. M. Barbano. 1985. Whole milk reverse osmosis retentates for Cheddar cheese manufacture: Chemical changes during aging. J. Dairy Sci. 68:1-10.

Carunchia Whetstine, M. E., K. R. Cadwallader, and M. A. Drake. 2005a. Characterization of rosy/floral flavors in Cheddar cheese. J. Agric. Food Chem. 53:3126-3132.

Carunchia Whetstine, M. E., A. E. Croissant, and M. A. Drake. 2005b. Characterization of dried whey protein concentrate and isolate flavor. J. Dairy Sci. 88:3826-3839.

Christensen, K. R., and G. A. Reineccius. 1995. Aroma extract dilution analysis of aged cheddar cheese. J. Food Sci. 60:218-220.

Cometto-Muniz, J. E. 1981. Odor, taste, and flavor perception of some flavoring agents. Chem. Senses 6:215-218.

Delahunty, C. M., J. R. Piggott, J. M. Conner, and A. Paterson. 1996. Comparative volatile release from traditional and reduced-fat Cheddar cheeses upon mastication in the mouth. Ital. J. Food Sci. 2:89-98.

Dimick, P. S., N. J. Walker, and S. Patton. 1969. Occurrence and biochemical origin of aliphatic lactones in milk fat-A review. J. Agric. Food Chem. 17:649-655.

Drake, M. A., S. McIngvale, P. Gerard, K. R. Cadwallader, and G. V. Civille. 2001. Development of a descriptive language for Cheddar cheese. J. Food Sci. 66:1422-1427.

Drake, M. A., and B. G. Swanson. 1995. Reduced and low-fat cheese technology: A review. Trends Food Sci. Technol. 6:366-369.

Engel, W., W. Bahr, and P. Schieberle. 1999. Solvent assisted flavour evaporation-A new and versatile technique for the careful and direct isolation of aroma compounds from complex food matrices. Eur. Food Res. Technol. 209:237-241.

Engels, W. J. M., R. Dekker, C. de Jong, R. Neeter, and S. Visser. 1997. A comparative study of volatile compounds in the watersoluble fraction of various types of ripened cheeses. Int. Dairy J. $7: 255-263$.

Fox, P. F., T. P. Guinee, T. M. Cogan, and P. L. H. McSweeney. 2004. Pages 249-255 in Fundamentals of Cheese Science. Aspen Publications, Gaithersburg, MD.

Gorski, D. 1998. Promoting cheese. Dairy Foods 99:51-52.

Grosch, W. 1993. Detection of potent odorants in foods by aroma extract dilution analysis. Trends Food Sci. Technol. 4:68-73.

Hall, G., and J. Andersson. 1985. Flavor changes in whole milk powder during storage. III. Relationships between flavor properties and volatile compounds. J. Food Qual. 7:237-253.

Johnson, M. E., and C. M. Chen. 1995. Technology of manufacturing reduced-fat Cheddar cheese. Pages 331-337 in Chemistry of Structure-Function Relationships in Cheese. Plenum Press, NY.

Karagul-Yüceer, Y., K. R. Cadwallader, and M. A. Drake. 2002. Volatile flavor components of stored nonfat dry milk. J. Agric. Food Chem. 50:305-312.

Karagul-Yüceer, Y., M. A. Drake, and K. R. Cadwallader. 2003. Aroma-active components of liquid Cheddar whey. J. Food Sci. 68:1215-1219.

Landy, P., S. Rogacheva, D. Lorient, and A. Voilley. 1998. Thermodynamic and kinetic aspects of the transport of small molecules in dispersed systems. Colloids Surf. B Biointerfaces 12:57-65.

Law, B. A., M. E. Sharpe, H. R. Chapman, and B. Reiter. 1972. Relationship of milk fat globule membrane material to flavor development in Cheddar cheese. J. Dairy Sci. 56:716-723.

Li, Z., R. Marshall, H. Heymann, and L. Fernando. 1997. Effect of milk fat content on flavor perception of vanilla ice cream. J. Dairy Sci. 80:3133-3141.

Lynch, J. M., D. M. Barbano, and J. R. Fleming. 2002. Determination of the total nitrogen content of hard, semihard and processed cheese by the Kjeldahl method: Collaborative study. J. AOAC 85:445-455.
Marshall, R. T., ed. 1992. Standard Methods for the Examination of Dairy Products. 16th ed. Am. Publ. Health Assoc., Inc., Washington, DC.

McGugan, W. A., D. B. Emmons, and E. Larmond. 1979. Influence of volatile and nonvolatile fractions on intensity of Cheddar cheese flavor. J. Dairy Sci. 62:398-403.

McSweeney, P. L. H., and P. F. Fox. 2004. Metabolism of residual lactose and of lactate and citrate. Pages 361-372 in Cheese: Chemistry, Physics, and Microbiology. 3rd ed. Vol. 1: General Aspects. Elsevier Ltd., London.

Meilgaard, M. M., G. V. Civille, and B. T. Carr. 1999. Selection and training of panel members. Pages 174-176 in Sensory Evaluation Techniques. 3rd ed. CRC Press, Boca Raton, FL.

Milo, C., and G. Reineccius. 1997. Identification and quantification of potent odorants in regular-fat and low-fat mild Cheddar cheese. J. Agric. Food Chem. 45:3590-3594.

Mistry, V. V. 1995. Improving the sensory characteristics of reducedfat cheese. Pages 371-381 in Chemistry of Structure-Function Relationships in Cheese. E. L. Malin and M. H. Tunick, ed. Plenum Press. New York, NY.

National Marketing Institute. 2000. Natural Marketplace Trends Report. Natl. Marketing Inst., Harleysville, PA.

Nauth, K. R., and D. Ruffie. 1995. Microbiology and chemistry of reduced-fat cheese. Pages 345-358 in Chemistry of StructureFunction Relationships in Cheese. E. L. Malin and M. H. Tunick, ed. Plenum Press, New York, NY.

Nelson, B. K., and D. M. Barbano. 2004. Reduced-fat Cheddar cheese manufactured using a novel fat removal process. J. Dairy Sci. 87:841-885.

Plug, H., and P. Haring. 1993. The role of ingredient-flavor interactions in the development of fat-free foods. Trend Food Sci. Technol. 4:150-154.

Prindiville, E. A., R. T. Marshall, and H. Heymann. 1999. Effect of milk fat on the sensory properties of chocolate ice cream. J. Dairy Sci. 82:1425-1432.

Prindiville, E. A., R. T. Marshall, and H. Heymann. 2000. Effect of milk fat, cocoa butter, and whey protein fat replacers on the sensory of lowfat and nonfat chocolate ice cream. J. Dairy Sci. 83:2216-2223.

Relkin, P., M. Fabre, and E. Guichard. 2004. Effect of fat nature and aroma compound hydrophobicity on flavor release from complex food emulsions. J. Agric. Food Chem. 52:6257-6262.

Roberts, D. D., P. Pollien, N. Antille, C. Lindinger, and C. Yeretzian. 2003a. Comparison of nosespace, headspace, and sensory intensity ratings for the evaluation of flavor absorption by fat. J. Agric. Food Chem. 51:3636-3642.

Roberts, D. D., P. Pollien, and B. Watzke. 2003b. Experimental and modeling studies showing the effect of lipid type and level on flavor release from milk-based emulsions. J. Agric. Food Chem. 51:189-195.

Roudnitzky, N., H. Irl, G. Roudaut, and E. Guichard. 2002. Influence of fat nature on flavour release. Pages 136-139 in Flavour Research at the Dawn of the Twenty-First Century, 10th Weurman Flavour Research Symposium. J. L. Le Quere and P. X. Etievant, ed. Lavoisier, Paris, Beaune, France.

Rychlik, M., P. Schieberle, and W. Grosch. 1998. Compilation of Thresholds, Odor Qualities, and Retention Indices of Key Food Odorants. Deutsche Forschungsanstalt fur Lebensmittelchemie and Institut fur Lebensmittelchemie der Technischen Universitat Munchen, Garching, Germany.

Salles, C., C. Herve, C. Septier, D. Demaizieres, I. Lesschaeve, S. Issanchou, and J. L. Le Quere. 2000. Evaluation of taste compounds in water-soluble extract of goat cheeses. Food Chem. 68:429-435.

Seuvre, A. M., M. A. Espinosa Diaz, and A. Voilley. 2000. Influence of the food matrix structure on the retention of aroma compounds. J. Agric. Food Chem. 48:4296-4300.

Singh, T. K., M. A. Drake, and K. R. Cadwallader. 2003. Flavor of Cheddar cheese: A chemical and sensory perspective. Comp. Rev. Food Sci. Food Safety 2:1-23. 
Sloan, E. A. 2001. Top 10 trends to watch and work on-3rd biannual report. Food Technol. 55:38-58.

Suriyaphan, O., M. A. Drake, and K. R. Cadwallader. 1999. Identification of volatile off-flavors in reduced-fat Cheddar cheeses containing lecithin. Lebensm. Wiss. Technol. 32:250-254.

Swaisgood, H. E. 1996. Characteristics of milk. Pages 841-876 in Food Chemistry. 3rd ed. O.R. Fennema, ed. Marcel Dekker, New York, NY.

Taborda, G., E. Molina, I. Martinez-Castro, M. Ramos, and L. Amigo. 2003. Composition of the water-soluble fraction of different cheeses. J. Agric. Food Chem. 51:270-276.
Upadhyay, V. K., P. L. H. McSweeney, A. A. A. Magboul, and P. F. Fox. 2004. Pages 391-434 in Cheese: Chemistry, Physics, and Microbiology. 3rd ed. Vol. 1: General Aspects. Elsevier Ltd., London, UK.

Van den Dool, H., and P. Kratz. 1963. A generalization of the retention index system including linear programmed gas liquid partition chromatography. J. Chromatogr. 11:463-471.

Van Ruth, S. 2001. Methods for gas chromatography-olfactometry: A review. Biomol. Eng. 17:121-128.

Woteki, C. E., and P. R. Thomas. 1993. Pages 1-7 in Eat for Life. Harper Collins Publ., Inc., New York, NY. 